\title{
Effect of Smart Classroom Learning Environment on Academic Achievement of Rural High Achievers and Low Achievers in Science
}

\author{
Prakash Chandra Jena \\ School of Education and Humanities, Lovely Professional University, Punjab - 144411, India \\ E-mail address: drpcjena@gmail.com
}

\begin{abstract}
The present study is an experimental one and conducted in Jalandhar district of Punjab. The investigators has taken 60 secondary school students from Royal Convent School by using simple random sampling technique. For conducting experiment the investigator has used two group randomized pre-test and post-test design. For collection of data the investigator has used an achievement constructed and standardized by the investigator and t-test has also used for analysis and interpretation data. The result of the study reveals that smart class learning environment is better to teach both low achievers and high achievers than traditional class.
\end{abstract}

Keywords: Smart Classroom Learning Environment; low achievers and high achievers

\section{INTRODUCTION}

In the context of global policy, global society and global economy, each and every country is seriously thinking of heightening the degree of quality in system of education. Globalization has permitted technical progress in communication field which enables users to access and exchange information at anytime and from any place in the world. Technology plays a vital role in education. In today's competitive world the child needs the skill sets, which are beyond subject knowledge and require concentration, assimilation power and retention. In this regard the role of smart class is quite important. Smart class is introduced by Educomp. Educomp is one of the largest education company in India taking care of entire education life cycle of students. The company currently works with over 26000 schools and over 15millons learners and educators across the world Educomp is India's largest K-12 content library of rich 3D multimedia educational content modules. It's founder is Shantanu Prakash. It's headquarter is in Gurgaon. In India is has 10 offices. The company works closely with schools to implement innovative models to create and deliver content to enhance student's learning.

In the last eight years over 80 million smart class sessions have been held in schools. This has given Educomp some invaluable insights into the real challenges that teacher encounter and their ever growing expectations from the program. These insights have helped to understand the pain areas to develop a whole new school transformation system. Educomp has now flagged off, the next generation of smart class. In smart class transformation system (CTS) and the smart class digital teaching system (DTS) are the biggest and most innovative 
initiatives in the space of digital classroom hardware respectively. Bhattacharya (1999) investigated the critical view of work done on the use of computer as instructional tool for teaching chemistry.

The main objectives of the study were to aim at developing tools for evaluating the effectiveness of available software in chemistry study and development of software in different areas of chemistry and they found that available software in chemistry was of good quality and most of the available software adopted lecture cum demonstration method in a class 20-40 minutes. The digital teaching system is world's first fully integrated one switch digital interactive teaching system, specially designed to work in high ambient temperatures and dusty conditions present in Indian class rooms. The class transformation system broadens the choice of teaching tool available with teacher beyond invaluable rich 3D animations to bring abstract concepts to life. The class transformation system poised as the next generation of Educomp smart class in schools, is the revolutionary leap forward in enabling excellence in schools.

Smart class is a digital initiative of Educomp, which is rapidly transforming the way teachers teach and students learn in schools with innovative and meaningful use of technology powered by world's largest repository of right next to the blackboard for teachers in the classrooms. Students learn difficult and abstract curriculum concepts.

Watching highly engaging visuals and animations. This makes learning an enjoyable experience of students while improving their overall academic performance in school. Smart class also enables teachers to assess and evaluate the learning achieved by their students in class with an innovative assessment technology smart assessment system designed by Educomp. Delivery model smart class has unique delivery model for schools. A knowledge center is created inside the school equipped with the entire library of smart class digital content. The knowledge centre is connected to smart room through intranet. Teachers get relevant digital resources such as animations and videos interactive virtual labs tools etc. and use them as a part of their lesson plan in every class rooms are equipped with state of art infrastructure complete with custom designed electronic interactive white board, projection system PC's and UPS Ena.

Smart class is equipped with tools such as:

○ The Science teacher can use a diagram drawer which plays a step by step line drawing animation.

- Teacher can get a brilliant teaching idea by clicking on teaching idea icon before teacher commences teaching or use topic synopsis or mind map to recapitulate the salient points of a lesson or concept taught.

○ There are worksheets, web links for more information on lessons/topics taught.

Support and training a team of over 1000 professionals of Educomp stand fully dedicated to support schools and teachers on day to day basis. Armed with highly evolved methodologies, tools and processes to help schools absorb the benefit of smart class. Smart class is mapped to the curriculum of state boards, CBSE and ICSE.

Smart class is a digitized classroom, which is rapidly transforming the way teachers teach and students learn in school with innovative and meaningful use of technology, powered by the world's largest repository of digital content mapped to Indian school curriculum, smart class brings in technology right next to the blackboard for teachers in the classrooms. Debi (2003) concluded that students performed better when exposed to program teaching material perform learning material was found to be effective compare to the traditional method of teaching. Smart class room technology known as interactive whiteboard 
that is used by classrooms all over. The interactive white board is huge screen that is mounted to a wall of the classroom. It is brought into class room it can serve a number of purposes.

Natrajan (2004) evaluated technology enhanced learning and future of education. The objective of the study to describe the several aspect of relating to TEL, the roll of multimedia and CD-Rom technology, role and impact of internet, e-learning.

Benefits of Smart Class

- Improves teachers effectiveness and productivity in class

- It brings abstract and difficult curriculum concepts inside classrooms.

- Makes learning an enjoyable experience for students.

- Improves academic performance of students.

- Enables instant formative assessment of learning out comes in class.

- It also enables teachers to instantly assess and evaluate the learning achieved by their students in class.

\section{Objectives of study}

- To study the difference in the effect of smart class room learning environment on academic achievement of low achievers in science

- To study the difference in the effect of smart class room learning environment on academic achievement of high achievers in science

\section{Hypotheses}

- There exists a significant difference between the academic achievement of low achievers who got and who did not get instructions in smart class room learning environment according to their pre-test and post-test

- There exists a significant difference between the academic achievement of high achievers who got and who did not get instructions in smart class room learning environment according to their pre-test and post-test

\section{METHOD AND DESIGN OF THE STUDY}

The present study was experimental in nature. After studying the review of related literature and considering the objectives of the study, Two group randomized matched pretest and post-test was to determine the effect of smart class on academic achievement of secondary school low and high achievers in science.

\section{1. Sampling}

All items in the field of inquiry constitute a universe or population. The selected respondents from the population which is technically called a sample and the selection process is called sampling. The investigator has taken 60 secondary school students as a sample. The classifications of the students as sample are given below: 


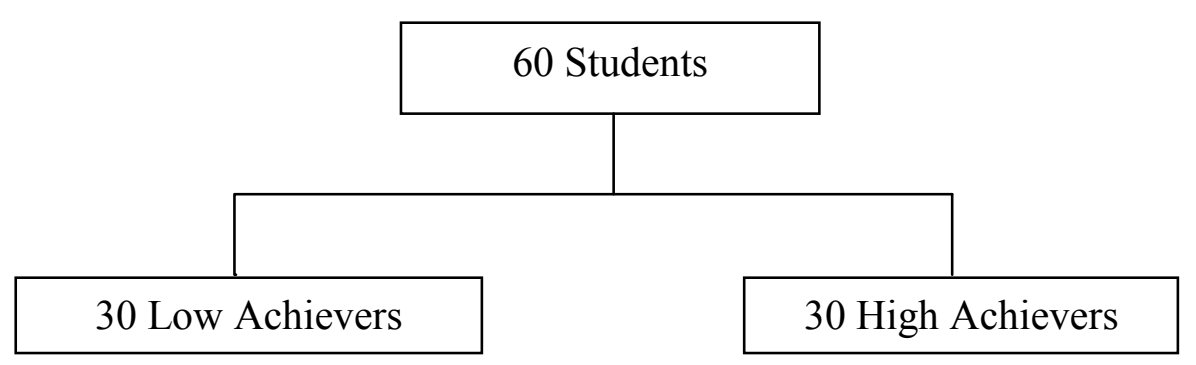

\section{2. Tools used}

For collect data the investigator has used an achievement test constructed by himself.

\section{3. Construction of achievement test}

Following steps were followed to make achievement test:

(a) Planning of the test: The construction of tests were carried out by consideration of limitation under which the tests were developed. The expert opinions were taken for the construction of the tests. The items of both tests were prepared in English language and covered the topic "periodic classification of the elements". 50 questions were planned to conduct the test. students were asked to complete this in 50 minutes.

(b) Validity of the test: To final out what the test measures, it was decided to determine its face validity. For this, the experts opinion had been considered.

\section{4. Statistical technique used}

The collected data were analyzed to find out the initial difference if any, between the pre-test scores of the groups using t-test. After that, to determine the effect of teaching through both methods and to find out the extent of use of both methods by teachers, the scores were again subjected to t-test analysis.

\section{RESULT ANALYSIS AND MAIN FINDINGS}

\section{1. Results pertaining to the difference in effect of smart classroom learning environment on academic achievement of low achievers in science}

In order to find out the difference in the effect of smart classroom learning environment on academic achievement of secondary school students of low achievers in science t-ratio was calculated and result is presented Table 1.

Table 1 depicts that the calculated t-ratio of low achievers who got and who did not get instructions in smart class room learning environment according to their pre-test and post-test is 4.69 which is found to be significant at both levels

Therefore, it can be interpreted that there exists a significant difference in the effect of teaching through smart class on academic achievement of low achievers in science. Thus, the proposed hypotheses was accepted. The difference of mean and standard deviation of pre-test and post-test scores of low achievers taught through smart class and traditional method has shown in Graph 1. 
Table 1. Comparison of low achievers students on pre-test and post-test.

\begin{tabular}{|c|c|c|c|c|c|c||c||}
\hline Group & $\begin{array}{c}\text { Method of } \\
\text { Instruction }\end{array}$ & $\mathrm{N}$ & Mean & $\mathrm{SD}$ & $\mathrm{df}$ & $\mathrm{SEd}$ & t- ratio \\
\hline $\begin{array}{c}\text { Experimental } \\
\text { Group }\end{array}$ & $\begin{array}{c}\text { Smart classroom } \\
\text { Learning } \\
\text { environment }\end{array}$ & 30 & 0.64 & 3.16 & & \\
\hline Control & $\begin{array}{c}\text { Traditional } \\
\text { Learning } \\
\text { Group }\end{array}$ & 30 & 25.00 & 4.05 & 5.93 & 4.69 \\
\hline
\end{tabular}

Level of significance $0.05=1.67$, Level of significance $0.01=2.39$

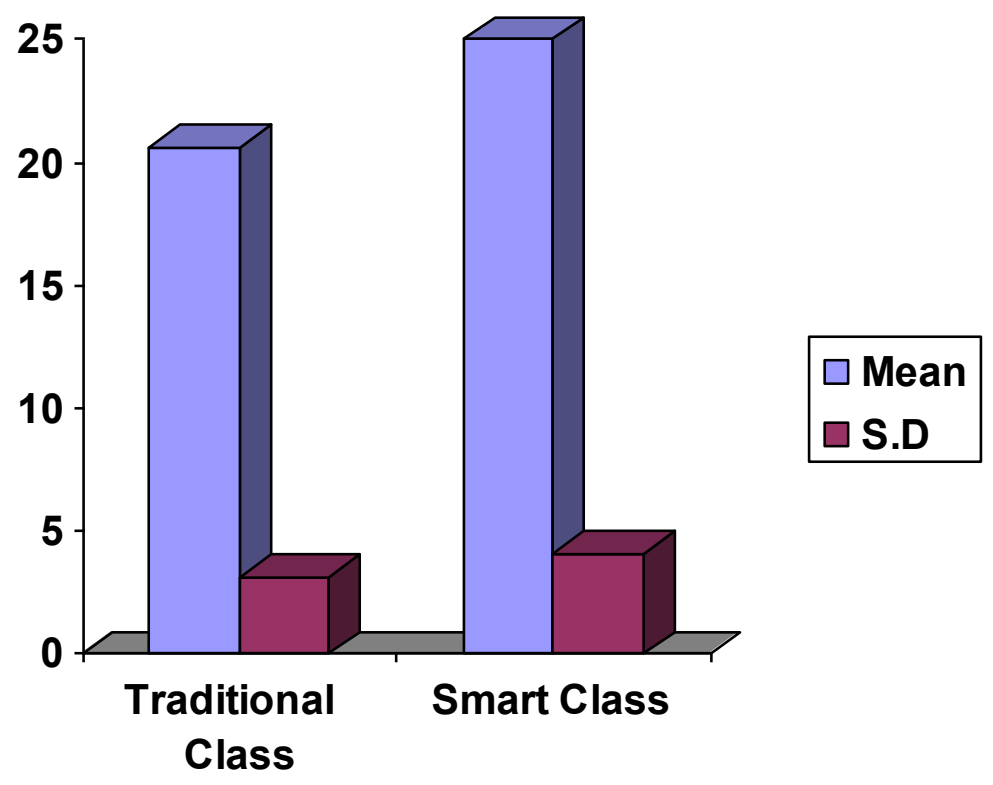

Graph 1. Bar Graph shows mean and standard deviation.

\section{2. Results pertaining to the difference in the effect of smart classroom learning environment on academic achievement of high achievers in science}

To find out the difference in the effect of smart classroom learning environment on academic achievement of secondary students of high achievers in science, t-value was calculated and result is presented in Table 2. 
Table 2. Comparison of high achievers students on pre-test and post-test.

\begin{tabular}{|c|c|c|c|c|c|c|c|}
\hline Group & $\begin{array}{l}\text { Method of } \\
\text { Instruction }\end{array}$ & $\mathrm{N}$ & Mean & SD & $\mathrm{df}$ & SEd & t- ratio \\
\hline $\begin{array}{c}\text { Experimental } \\
\text { Group }\end{array}$ & $\begin{array}{c}\text { Smart } \\
\text { classroom } \\
\text { Learning } \\
\text { environment }\end{array}$ & 30 & 30.10 & 5.12 & \multirow[t]{2}{*}{58} & \multirow[t]{2}{*}{1.25} & \multirow[t]{2}{*}{3.28} \\
\hline $\begin{array}{l}\text { Control } \\
\text { group }\end{array}$ & $\begin{array}{c}\text { Traditional } \\
\text { Learning } \\
\text { Environment }\end{array}$ & 30 & 43.2 & 4.77 & & & \\
\hline
\end{tabular}

Level of significance $0.05=1.67$, Level of significance $0.01=2.39$

The Table no. 2 depicts that the calculated t-ratio of high achievers who got and who did not get instructions in smart class room learning environment according to their pre-test and post- test is 3.28 which is found to be significant at both levels. Therefore, it can be interpreted that there exists a significant difference in the effect of teaching through smart class on academic achievement of high achievers in science. Thus, the proposed hypotheses was accepted. The difference of mean and standard deviation of pre-test and post-test scores of high achievers taught through smart class and traditional method has shown in graph no. 2

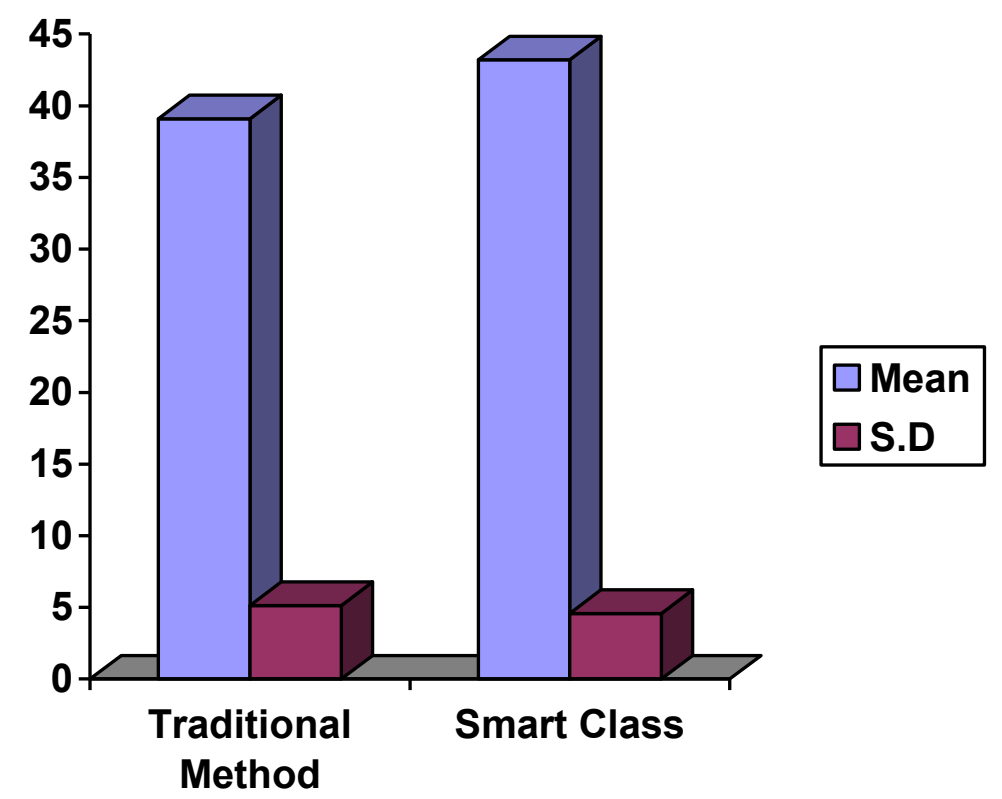

Graph 2. Bar Graph shows mean and standard deviation. 


\section{MAIN FINDING AND CONCLUSION} drawn.

On the basis of analysis and interpretation of data, the following conclusion can be

* There exists a significant difference in the effect of smart class room learning environment on academic achievement of low achievers of secondary students in science. The results shows that the students taught through smart class have scored better academic achievement than students taught through traditional method. The reasons of performing well by students taught through smart class may be:

- Smart class learning helped to develop cognitive dimension.

- Reinforcement given to all students on every improvement.

- Organization of the corrective activities

- Formative tests conducted to find out the progress.

- Supplementary material provided to students.

* There exists a significant difference in the difference of effect of smart classroom learning environment on academic achievement of high achievement of high achievers of secondary students in science. The results shows that the students who are high achievers have also scored better academic achievement taught through smart class than taught through traditional method. The reasons of performing well by high achievers may be:

- Motivation and Reinforcement given to all students on every improvement. Because smart class created much interest than traditional method

○ Organization of the corrective activities.

- Formative tests conducted to find out the progress.

- Creation of enjoyable environment in class.

\section{Suggestions}

The researcher by virtue of his experience in conducting this study, Would like to put forward the following suggestions:

* Sample size can enlarged to more concrete results.

* A sample study can be carried on primary level, senior secondary level, college level and university level students.

* Similar study can be analyzed by different statistical techniques for verifying the results

* Comparison can be made between boys and girls.

* The same study can be conducted on other subjects of science also.

* The effectiveness of the methods can be seen by giving a longer duration of teaching.

\section{Recommendations}

Based on the finding and conclusions of the study the following recommendations are put forward.

* Smart class room learning help to increase the learning abilities.

* Smart class may use as a supplementary learning tool to teaching low IQ level students and high IQ level students. 
* The curriculum should be framed keeping in view the application of smart classes of teaching.

* This strategy helps the learner to move at his own pace as it helps the learners to provide individual instruction.

* Although students generally work together in small groups in hands on science classes, there are times when all class discussions are valuable. Summarizing comparing, and interpreting often involves the whole class. Teachers can use both small group and whole class approaches to teaching science, and discuss when each may be appropriate.

* Science classes involve all the challenges of regular classrooms with some additional ones besides

The program of science education should focus on some of the things teaching science:

- Working with diverse student populations.

- Stimulating interest in science among students.

- Using scientific vocabulary, only as necessary.

- Helping students believe their voices are valued.

- Promoting students discussion yet keeping it focused.

- Treating students with respect and facilitating learning with multiple learning modalities.

- Better student teaches understanding and relationships, better adaptation of teaching learning, encouragement of students towards acceptance of responsibility of learning, greater satisfaction of student with his learning etc should be given importance.

\section{References}

[1] Allen B., Second Survey of Research in Education: New Delhi 13 (2009) 14-22.

[2] Ainley Mary, Hidi Suzanne, Berndorff Dagmar, Journal of Educational Psychology 94(3) (2002) 545-561.

[3] Burnand et al., Social Science Research Unit Institute of Education 6 (2004) 5-16.

[4] Dhamija K., A Computer Study of Effectiveness of these Approaches of InstructionsConventional, Radio-Vision and Modular Approach on Achievement of Students in School Studies, Ph.D Dissertation Delhi University, Delhi 2000.

[5] K. Dalacosta, M. Kamariotaki-Paparrigopoulou, J. A. Palyvos, N. Spyrellis, Computers and Education 52 (4) (2009) 741-748.

[6] Ena Howse, Effect of Smart Board Interactive White Board on Concept Learning, Generation of Ideas, group process and user Interactive Satisfaction, 2000.

[7] Gupta N. K., Research in Teaching of Science. New Delhi: APH Publishing Corporation 2007.

[8] Gosh B. N., Scientific Methods and Social Research. New Delhi: Sterling Publishers Private Limited 1999.

[9] Kumar et al., Indian Educational Review 27(3) (2000)16-34. 
[10] Sidhu N. S., Computer Applications in Education for the M.Ed. (Educational Technology) Course, M.Ed. Dissertation, Punjab University Chandigarh 2002.

[11] Sahoo P. K., Educational Media Research and Instructional Management of Distance Education 11(1995)

[12] Tuzun et al., Computer and Education 52(1) (2009) 68-77.

[13] Raziye et al., Journal of Computer ICT in Education 2(12) (2010) 841-851.

[14] Ray P. K. S., Technology of Instructional Design. (Part-1), Dominant Publication, New Delhi 2006.

[15] Rose and Stella, Journal of Educational Research 32 (1) (2005). 